Cahiers $d u$ MONDE RUSSE

\section{Cahiers du monde russe}

Russie - Empire russe - Union soviétique et États indépendants

$53 / 4 \mid 2012$

Varia

\title{
Natalja Šlihta, Cerkva tyh, hto vyžyv
}

\section{John-Paul Himka}

\section{OpenEdition \\ Journals}

\section{Electronic version}

URL: http://journals.openedition.org/monderusse/7871

DOI: 10.4000/monderusse.7871

ISSN: $1777-5388$

\section{Publisher}

Éditions de l'EHESS

\section{Printed version}

Date of publication: 15 December 2012

ISSN: $1252-6576$

\section{Electronic reference}

John-Paul Himka, « Natalja Šlihta, Cerkva tyh, hto vyžyv », Cahiers du monde russe [Online], 53/4 | 2012, Online since 08 October 2013, Connection on 23 September 2020. URL : http://

journals.openedition.org/monderusse/7871; DOI : https://doi.org/10.4000/monderusse.7871

This text was automatically generated on 23 September 2020

(c) École des hautes études en sciences sociales 


\title{
Natalja Šlihta, Cerkva tyh, hto vyžyv
}

\author{
John-Paul Himka
}

\section{REFERENCES}

Natalja ŠLIHTA, Cerkva tyh, hto vyžyv. Radjans'ka Ukrajina, seredyna 1940-h - poč

atok 1970-h rr. [The church of those who survived: Soviet Ukraine, mid-1940s beginning of the 1970s]. Harkiv : Akta, 2011, 467 p.

1 This exemplary monograph is divided into three parts. The first (p. 37-130) concerns the situation of the Russian Orthodox church (ROC) as a whole from late Stalinism, through Khrushchev's antireligious campaign, to the normalization of the early Brezhnev era. The second (p.131-250) narrows the focus to the ROC's Ukrainian exarchate; and the third (p. 251-382) narrows it even more, to the formerly Greek Catholic, as of 1946 "reunified" church - what Natalja šlihta calls the "church within the church" - based in the three Galician oblasts and Transcarpathia. The research base is extensive: archival documents (particularly the papers of the Council that acted as intermediary between church and state), official church publications, interviews, and all the relevant secondary literature in English, Russian, and Ukrainian. The emphasis is on the sociology and anthropology of the churches rather than on politics or religious studies, although it sheds light on both those topics as well. The author sees her work as a study of postwar Soviet everyday life, Soviet social history, an anthropology of Soviet society.

2 The circumstances of the ROC after its partial restoration in 1943 are portrayed from a fresh perspective. Although now ready to tolerate a church, the postwar Soviet state wished as much as possible to isolate it from society. The measures it took to do so included banning the study of homiletics and logic in seminaries in order to limit priests' potential to influence. The state tried to make clerical education into narrow vocational training, while bishops and church educators constantly sought to expand courses in history and even in Marxist thought. Sometimes central and local authorities had different attitudes toward the social activities of the ROC. The center wanted to 
keep the church out of the public sphere altogether, but the local levels were happy when the church took responsibility for the maintaining cemeteries or dispatched priests to encourage collective farmers to fulfill their obligations on time. The church wanted to integrate into Soviet society and create for itself a Soviet identity. But the party and state distrusted what they considered to be opportunism and adaptation. As šlihta points out, it has been fairly normal for churches to adapt to political and social circumstances, but adaptation to a hostile, atheist state was particularly challenging. Several factors aided the church in working out a modus vivendi with the regime. The ROC and the Soviet state could find common ground in Russocentrism and Russian patriotism. Also, the ROC was a ritually oriented, liturgical church that expended much of its energy on the provision and performance of various church services. And finally, the church (like most Soviet citizens and institutions, šlihta argues) made use of "doublethink," i.e. holding two sets of contradictory beliefs and acting in accordance with them, but selectively in different contexts. Overall, šlihta paints a convincing, modelled portrait of the outlook of the ROC in the decades following World War II.

She then uses the Ukrainian exarchate as the basis for an exploration of how the church actually functioned in the Soviet polity. In what she characterizes as a tactic of "small deeds," the Ukrainian episcopate struggled to provide sufficient and sufficiently qualified priests to minister to the liturgical and sacramental needs of the population. Owing to the intervention of the state, the seminaries did not produce enough candidates for the priesthood, and many of those they did produce were poorly educated. Bishops tried to make up for the educational deficits by organizing supplementary courses and workshops for the clergy. To make up for the sheer shortage, the hierarchs ordained deacons who had not finished seminary, psalmists, and even lay activists. They circulated priests from parish to parish to maximize opportunities for provision of the sacraments. (Of course, this had deleterious results for pastoral care.) Bishops also used every excuse to offer archhierarchical services, which thousands would attend. Every one of these measures was fought by the Council, but bishops learned how to get around restrictions. It was not by open opposition. šlihta wrote an illuminating section (p. 154-171) contrasting the methods and achievements of two bishops: the oppositional Bishop Feodosij (Kovernyns'kyj) and the "doublethinking" Archbishop Palladij (Kamins'kyj). The former, who expressed his outright opposition to the atheistic regime, served only for a short time as an administrator of eparchies, accomplished almost nothing, and eventually had to obtain special permission even to celebrate the liturgy in private. The latter acted as much as possible as a traditional bishop, considering his authority over the clergy to be higher than that of the Council officials. But he was markedly pro-Soviet in his public pronouncements. He was able to accomplish a good deal for the faithful under his care, by various methods expanding pastoral services, finding candidates to ordain to the priesthood, and improving his clergy's education.

4 Another interesting section in the second part of the monograph concerns baptisms. The state was not overly worried by the baptism of infants, which it regarded more as a traditional rite than a religious statement, but it was disturbed by the baptism of children and adults. Yet such baptisms were a predictable occurrence in the aftermath of antireligious campaigns. Even more disturbing to the state were the mass baptisms that emerged in the mid-1950s. These were primarily urban phenomena, and one attraction of them for the participants was that they could become anonymous within the collectivity. Mass baptisms were held not only on Christmas and Easter, but also on 
1 January, 1 May, and 7 November. "Such baptisms did not simply serve to meet the religious needs of the population. They were an alarming sign for a regime that sought to completely isolate the church. The timing of the rite of baptism simultaneously with a Soviet holiday in order to give more solemnity to this family event testified eloquently that the antiquated religious rite remained important for the secularized population. Such timing helped to maintain the symbolic connection between the church and Soviet society. It is significant that there are testimonies to the particular popularity of this ceremony among the intelligentsia and the working population of Kyiv and of the great industrial centers of the East and South of Ukraine." (p. 183)

The third part of the monograph concerns the church within the church that resulted from the "reunification" of the Greek Catholic church in Galicia and Transcarpathia with the ROC in 1946. This constituted a disproportionately large part of the Ukrainian exarchate. In 1950, 40 percent of the exarchate's churches were formerly Greek Catholic as was a fifth of its clergy (p. 375). After Khrushchev's antireligious campaign managed to close down many parishes in the rest of Ukraine, the disproportionate weight of the church in the western oblasts increased. Although this church within the church had many specific features, the same patterns of behavior identified for the ROC as a whole and for the Ukrainian exarchate as a whole were also at work here.

Šlihta engages in a careful analysis of the role of the ROC in the "reunification" itself, identifying and avoiding two oversimplifications present in the existing literature: that the ROC worked closely and willingly with the regime to abolish the Greek Catholic church and that the ROC engaged in this project only with reluctance. What she shows instead is that the ROC exploited the situation - its usefulness for "Orthodoxizing" and hence helping to integrate Western Ukrainian society - in order to gain concessions from the state for its religous mission.

7 Šlihta considers that in the given situation the choice of most Greek Catholics to enter the ROC was the natural one. As she puts it: "The church in the Soviet state had to choose between institutional survival and refusal to compromise. The choice of the latter afforded the opportunity to feel like 'martyrs for the faith.' But in circumstances when the primary task was to secure provision for the religious needs of a flock of millions..., this was hardly a viable alternative" (p. 285-286). She demonstrates convincingly that the movement to Orthodoxy was a deliberate choice made by clergy and faithful to save what could be saved of Greek Catholic religious life. Greek Catholic priests who went over to Orthodoxy feared that Orthodox priests coming to Western Ukraine from the East would so alienate the local population that they would stop attending church altogether. This was not an unreasonable fear. Eastern Ukrainians who came as teachers and officials to Western Ukraine were often despised by the local population, which resented Soviet rule and the importation of the Russian language. The "reunified" priests and hierarchy used the sensitivities of the local population as a justification for retaining Greek Catholic practices and devotions, such as liturgies that were read rather than sung and the cult of the Sacred Heart. Šlihta shows that the first bishops of this "church within the church," Myhajil (Mel'nyk) and Antonij (Pel'vec'kyj) were both "Uniates in disguise"; and she feels that it is not surprising that both of them were killed (as was the most prominent initiator of the move to Orthodoxy, Fr. Gavryjil Kostel'nyk) by the security organs.

8 In the mid-1950s the so-called "catacomb" church emerged in the western oblasts, as clergy who had refused to sign a declaration of Orthodoxy returned from exile and 
imprisonment. Šlihta shows that whatever tensions existed between the church within the church and the catacomb church, the primary element of their relationship was mutual support. The church within the church provided necessary liturgical and sacramental services to a larger population, and its clergy often helped out the underground Greek Catholic clergy. As of the mid-1960s, the hierarchy of the catacomb church accepted clergy from the church within the church into the Greek Catholic church, and some priests functioned under the double jurisdiction of the ROC and of the Ukrainian Greek Catholic church. For its part, the hierarchy of the church within the church used the activization of the underground Greek Catholic church as an instrument to increase its importance in the eyes of the state, now threatened by an underground religious movement. In the 1960s, after the release of the exiled Greek Catholic metropolitan Josyf (Slipyj) to the West and as a result of the sessions of the Second Vatican Council, the hierarchs of the church within the church claimed increased competition from the Greek Catholics, which they could only win by expanding their pastoral network and further Ukrainianizing the church. They magnified the Greek Catholic threat in order to lobby for such things as the reestablishment of local seminaries in Western Ukraine and the publication of Ukrainian-language Gospel books and church calendars.

9 After coming to the end of this fascinating text, one finds valuable appendices and, of course, a bibliography and personal and place name indexes. What one also finds - and this is rare for Ukrainian publications - is a subject index.

10 All in all, this is a well researched and innovative book, to be recommended to all interested in Soviet history of the postwar period, in Russian Orthodoxy, and in Ukrainian religion. 